\title{
ÉDIPO ENTRE PRIAPO E PROMETEU
}

Kathrin Holzermayr Rosenfield

Psicanalista, professora do departamento de Filosofia da UFRGS

RESUMO: Analisa-se a insistente simbologia fálica na tragédia de Sófocles. Discute-se os el os poéticos entre as imagens da integridade física que favorecem os potenciais naturais e libidinosos (as afinidades do herói com daimones como Pã ou Sátiros) e as figuras do saber e das conquistas intelectuais ( cujo herói paradigmático é Prometeu).

Palavras-chave: Imaginário da caça, relação natureza-cultura.

ABSTRACT: 0 edipus between Priap and Prometheus. This article analyses the insistent phallic symbols in Sophocles' tragedy. It discusses the poetical links between images of physical integrity favoring natural, libidinous potentials (Oedipus' affinities with demons like Pan or Satyrs) and the figures of knowledge and intellectual achievement (whose prototype is Prometheus).

Keywords: Images of hunting, relationship of images of nature and culture.

"A justiça quer que 0 saber vá àqueles que sofrem."

(Ésquilo, Prometeu acorrentado, vs 249-251)

\section{ÉDIPO REI: A TRAGÉDIA DO SABER QUE EMERGE DO CORPO}

O modo convencional de ler Édipo Rei de Sófocles começa em geral pela focalização de seus dotes sapienciais. Proporemos aqui seguir a perspectiva do poeta Hölderlin, cujo olhar ultra passou rapidamente esta primeira aparência, detectando os sinais de um pavor que funciona ao mesmo tempo como motor e como impedimento do saber. Édipo Rei é o salvador deTebas. A charada poética da Esfinge é um enigma fácil para o jovem herói, que antecipa na solução do mesmo a experiência de 
uma vida inteira (as três idades: infância, idade adulta, senilidade). Mas os fragmentos vividos e espal hados pelo tempo, dissipados e mergulhados no esquecimento, constituem um enigma que o homem adulto tem infinita dificuldade em ver, reunir, ler - legèn em grego é entender, compreender, dizer-revelar “juntando ossinhos" do passado... É isto o que o herói tenta fazer quando começa, solene, com a investigação da morte de Laio. No entanto, basta uma alusão ao segredo de sua origem e ele se precipita numa outra direção, procurando desvendar este segredo como se ele não tivesse nada a ver com sua tarefa inicial. Hölderlin viu bem onde está a verdadeira "Esfinge" do homem Édipo: ela está em toda parte, ela é o enigma que ele procura desvendar: "Quando Édipo está novamente tentado a viver", comenta o poeta alemão, "inicia o combate desesperado para voltar a si mesmo, o esforço brutal e quase despudorado de dominar-se a si mesmo, a procura, com fervor selvagem por uma consciência" (HOLDERLIN, 1988, p.249-258). ${ }^{1}$

Brutalidade, despudor e selvageria são as características da Esfinge... Os vasos dos séculosVI eV a mostram, lasciva e despudorada, "devorando" os belos mancebos deTebas. A tentação de viver, viver de qualquer jeito, eis a Esfinge de Édipo (e a nossa).

0 rei digno, que se mantém ereto no meio dos suplicantes, é torre firme e protetora da cidade, descobrirá bem mais do que sua identidade. Descobrirá que a identidade de quem quer viver de qualquer jeito é insustentável. No início de Édi po Rei, de Sófocles, ele él era um rei digno, que reergueu a cidade. Reprimindo os desmandos da Cantora, ele garantiu as boas regras de sucessão e troca. Mas este emblema da construção reta e do regramento do tempo das uniões e sucessões dissolve-se (do início ao fim da peça) no lento e doloroso desvendamento dos pequenos "detal hes" que causaram o pântano das relações incestuosas e autofágicas nas quais afundou Tebas, que perdeu o ritmo regrado das gerações.

Esta dissolução - reviravol ta trágica que ocorre, sorrateira, a cada instante da progressão da peça/ vida/ trajetória - é o problema que realmente se coloca para Édipo (e para nós). Ele exige que enfrentemos (nós, os espectadores, e 0 herói dentro da peça) um desamparo bem maior do que se esperava, um abismo insuspeitado de crueldade "invisível", embora os sinais desta violência originária estejam em toda parte. 0 herói não o vê, porque separa a questão da morte de Laio - a dúvida sobre o ocorrido na tripla encruzilhada - da pergunta sobre a

\footnotetext{
${ }^{1}$ Com relação ao texto de Holderlin, usaremos aqui algumas siglas: FHA remete à edição SämtlicheW erke, Frankfurter Ausgabe, v.16, Stromfeld/ Roter Stern, 1988, "Anmerkungen zum Oedipus" (Observações sobre Édipo); H indica a numeração da tradução hölderliniana do texto de Sófocles; BL refere-se à tradução de Mazon (Paris, Les Belles Lettres, 1985), cuja numeração dos versos segue a das outras edições já consagradas.
} 
própria origem - a suspeita de seu nascimento vil, filho de escravos ou filho rejeitado. Este enigma que o fascina a ponto de fazêlo esquecer a investigação da morte de Laio, ele somente 0 admite atribuindo-o a Jocasta, quando poderia lêlo nas marcas dos seus pés. ${ }^{2} \mathrm{~N}$ ópice da angústia, el e encoraja a rainha de não se envergonhar de sua origem vil, uma vez que ele é filho de escravos, igualando-se quase com as crias de animais domésticos, exortando-a a vê-lo como "filho da Sorte", quando ele mesmo não suporta ver e aceitar a vista dos seus pés mutilados. Clivando os signos da primeira e da segunda questão, a imagem que poderia fornecer a resposta se desfaz: Édipo se priva do reconhecimento de que a questão da integridade do velho rei Laio (isto é, sua integridade física como homem e sua legitimidade simbólica como rei deTebas) está intimamente relacionada com a ( falta de) integridade daquele que o abateu na tripla encruzilhada.

Assim, o herói percebe apenas muito tardiamente - e apenas obrigado pelo mensageiro que fala de sua cicatriz como de uma obviedade - que sua integridade simbólica, física e moral está minada por um "velho mal" inscrito nos seus pés. Na tragédia de Sófocles, a cicatriz não tem a função auxiliar de signo de reconhecimento, mas "encarna", por assim dizer, toda a problemática da postura, do posicionamento e dos deslocamentos, físicos e simbólicos, do herói no espaço e no tempo.

0 poeta $\mathrm{Hölderlin}$, atento como nenhum outro tradutor, aos pequenos detaIhes concretos (as posições físicas no tempo e no espaço, por exemplo, ou os modos concretos da expressão), salientou também os traços da experiência criatural dos heróis trágicos: os elos secretos que o homem civilizado mantém com a sel vageria da natureza e das feras. Seguindo as sugestões do poeta al emão, analisaremos com mais vagar de que maneira os sinaisfísicos (a cicatriz dos pés) são integrados na trama de signos que elaboram a trágica conjunção da finitude e do infinito da condição humana. Esta análise fará aparecer com mais nitidez as afinidades da figura sofocliana de Édipo com dois tipos antagônicos do imaginário clássico. De um lado, estão as figuras míticas da vida criatural (Pan e os outros personagens do séqüito de Dioniso), de outro, a figura esquiliana de Prometeu, ${ }^{3}$ paradigma do saber e das técnicas humanas.

\footnotetext{
2 É significativo, neste sentido, que o relato de Jocasta mencione claramente os pés perfurados (esfolados, encavados...) do recém-nascido ( $v .718$ ), e este, adulto, registre somente a menção à tripla encruzilhada.

${ }^{3}$ Vários críticos já assinal aram anal ogias que aproximam os dois heróis (em particular a arrogância e a implacabilidade, authadia, BL 907). Cf. Knox (1966, p.49) e Marshall (2000, p.154). Nossa análise prolonga esta reflexão, iluminando o traço antagônico ao da arrogância: o desamparo profundo, que é fundamental para a construção do paradoxo trágico.
} 


\section{O ENCONTRO NA ENCRUZILHADA}

0 que aconteceu no encontro na encruzilhada dos três caminhos?

Um viajante a pé não cede o caminho ao arauto de um velho rei, montado num carro puxado por mulas. 0 ancião o castiga com uma chicotada que 0 atinge na cabeça. $O$ solitário viajante é o príncipe de Corinto, Édipo, o “pé inchado", que se serve de um bastão. 0 bastão apóia pés frágeis? Ou é ele um signo de crueldade, um bastão-clava que logo abaterá o rei e seu séqüito? Ou um emblema da soberania - bastão-cetro - que deixa transparecer o direito ao trono deste filho (exposto porém sobrevivente) ? A arte de Sófocles deixa em aberto todas estas possibilidades, mostrando somente a faceta valente e vitoriosa do exilado príncipe de Corinto que conquista o trono graças aos seus méritos intelectuais.

O que permanece oculto no relato de Édipo são os sinais físicos que contribuíram para precipitá-lo na dúvida sobre sua origem. 0 jovem vitorioso da encruzilhada é um príncipe assolado por "tristes segredos". Rumores põem em dúvida seu parentesco com a casa real, sem esclarecer sob que condições o filho postiço teria sido introduzido no berço de Mérope e Políbio. Os protestos aflitos dos pais não apaziguam suas dúvidas, que assombram a honra genealógica, a identidade familiar e social. Édipo não menciona as cicatrizes dos seus pés, mas esta marca aviltante com certeza falou mais al to do que os protestos paternos que procuravam, em vão, rechaçar os rumores humilhantes. Em Delfos, a pergunta sobre pais é de novo rechaçada pelo silêncio deApolo e o herói recebe a assombrosa profecia que Ihe prediz o parricídio e o incesto. Há, portanto, uma nebulosa de sinais dúbios que imprime em Édipo o estigma do outcast. Ele se auto-exila, como um homem que sente ter perdido seu lugar na pólis e se vê obrigado à conquista errante de uma nova pátria.

Não pertencer à pólis, ser apólis, significa, no mundo antigo, uma violenta carência de estatuto social, um desamparo. $\mathrm{E}$ isto põe Édipo à mercê de estra nhos, fazendo-o dependente da hospitalidade alheia e de seu querer. É normal imaginar que um homem nesta situação possa perder toda sua lepidez aristocrática e que seu movimento corporal expresse as seqüelas da ferida antiga inscrita no nome Oidipous - " pé inchado". Não se trata de ver Édipo como literalmente coxo - aliás, Sófocles nunca fala de qualquer passo manco que poderia evocar a ferida dos tornozelos de seu personagem. No entanto, o texto remete de modo insistente ao "velho mal" dos pés machucados. A dor que Édipo expressa ao "lembrar" o que el e tenta esquecer mostra que não é pequena a marca do sofrimento que persegue o homem desde a infância.

Com os elementos que Sófocles espal ha no texto é possível imaginar que na tripla encruzilhada tenha-se revelado o triplo estigma do filho exposto de Laio: a fragilidade da dúbia filiação, a da dúbia valentia ou honra guerreira e a da dúbia 
sustentação física nos pés atingidos por uma ferida "esquecida". Ora, "esquecer" uma mutilação física exige forças mentais - e físicas - extraordinárias. 0 gemido doloroso de Édipo no momento em que o mensageiro-pastor menciona a marca dos pés mostra o peso que acarreta o "esquecimento" desta ferida. Ele revela o pavor abafado que se manifesta, talvez, também no torpor que o herói sente quando Jocasta menciona a tripla encruzilhada e... descreve como Laio amarrou os tornozelos do recém-nascido. Para quem lê apenas o que é dito de modo explícito, o herói parece sentir-se ileso até o momento em que o mensagei ro 0 obriga a reconhecer que seu nome corresponde à marca física que carrego nos pés. Mas para quem observa o ritmo dos acontecimentos, também 0 relato da rainha suscita as inquietudes do herói no exato momento em que ela menciona os pés amarrados, muito embora o herói admita falar somente da encruzilhada.

A vergonha "esquecida" dos pés machucados estoura muito tarde, num grito que expressa o que é anterior à vergonha: o pavor, o medo do despedaçamento que a imaginação costuma tecer em torno das feridas - até daquelas que cicatrizaram bem. Embora Édipo não queira isto, al go continuou pensando na cicatriz (e na fragilidade?) dos membros que deveriam assegurar sua firmeza. É com um gesto peremptório (ou reativo) com o qual o rei se colocou, como a torre forte e protetora da cidade. No grito "Ai, por que mencionas o vel ho mal", ele mostra, pela primeira vez, que sua firmeza é uma conquista: ela repousa sobre a eficácia de uma ficção, de uma ilusão necessária que exigiu o esquecimento ativo da marca física e simbolicamente aviltante.

Não subestimemos o referente físico e concreto das imagens discretas de Sófocles. Podemos - e devemos - imaginar que a atadura de Lai o, que feriu ( 0 texto diz: perfurou) os tornozelos do recém-nascido, tenha deixado seqüelas. Quem sabe, somente certa rigidez da articulação, uma predisposição somática para dores, inflamações e inchaços. Seja como for, pés inchados ou mal cicatrizados não favorecem as tarefas da guerra, nem as proezas esperadas de um guerreiro. Não seria esta a dor que "rói" e avilta a al ma do jovem Édipo que não consegue superar os rumores negados por seus pais?

$\mathrm{Na}$ Grécia arcaica e clássica, todo homem livre é posto à prova em enfrentamentos atléticos e na guerra. Até um poeta como Sófocles tem sua fama imortal porque soube lutar, além de escrever tragédias. Se atéhoje um péchato desqualifica o indivíduo para o serviço militar, é claro que no mundo antigo o mal dos "pés inchados" é, inevitavelmente, um estigma aviltante, uma mácula que atinge a virilidade e ameaça a honra e a estima subjetiva e objetiva de um homem.

Os códigos de valor e honra de Homero, por exemplo, sobrevivem na poesia trágica e os espectadores de Sófocles lembram-se das lendas nas quais Aquiles carrega o epíteto sobremaneira elogioso de "o dos lépidos pés" : corredor magnífico 
que se sustenta maravilhosamente nos seus pés ágeis, que lhe asseguram a supremacia no combate. Só uma flechada divina no tornozelo ou no tendão deAquiles consegue pôr limites à arrogância vitoriosa deste guerreiro. Contra esta tela de fundo, os traços reunidos por Sófocles desdobram o estigma da exclusão de Édipo em três registros - no plano físico (a falta de sustentação pela cicatriz nos pés), no genealógico (a carência de filiação) e no moral (a falta de legitimidade devido ao miasma). 0 velho mal, poderia, portanto, ser um "detal he" chave para compreender a suscetibilidade e o pendor de Édipo para a ira.

\section{AS CONOTAÇÕES FÁLICAS DO ENCONTRO}

0 texto de Sófocles espalha estes elementos em pequenas menções e conduz a descrição do encontro na encruzilhada com admirável economia poética. Para compreender o que realmente está em jogo quando Édipo surge no caminho e, na outra direção, aparece Laio, basta registrar a trama dos pequenos detal hes.

0 rei está montado num carro puxado por mulas e é acompanhado por um pequeno séqüito de cinco homens. Nada de grandioso, apenas o suficiente para demarcar de modo claro a imensa diferença de estatuto social. 0 vel ho homem de cabelos brancos se faz anunciar por um arauto que exige com orgulho que 0 anônimo viajante ceda a estrada ao rei que está a caminho de Delfos. 0 gesto de fria e apressada indiferença seria normal se 0 rei estivesse passando por um escravo ou um pobre pastor, mas ele infringe as regras da civilidade entre viajantes (MUSURILLO, 1957). 0 anúncio do arauto, sua ordem de retirada para dar espaço ao carro, o gesto arrogante do rei ao levantar o chicote para castigar a demora do viajante em ceder o caminho - tudo repete e reforça de modo insuportável a ferida do outcast, a fragilidade de quem tem motivos para suspeitar de sua integridade social, moral e física.

Neste contexto, cabe lembrar, ainda, os objetos falantes e fatídicos que pai e filho carregam na mão. Laio bate com o [chicote de] duplo ferrão (diploiskentroisi, BL 809) e é instantaneamente abatido pelo bastão/ cetro (skeptrô tupess, BL 811) . 0 raio semântico do kentron oscila entre 0 ferrão que estimula 0 animal e o objeto que excita o desejo erótico, emblema fálico que, em certos contextos, sinaliza a soberania. 0 mesmo vale para o bastão, skeptron, que, de um lado, apóia os passos do viajante ( ou os pés frágeis de Édipo?), de outro, transforma-se literal e repentinamente no cetro que afirma a soberania do filho sobre o pai. Apesar da extrema economia do relato, o poeta de Édi po Rei reuniu traços suficientes para evocar as conotações da rivalidade a um só tempo genealógica e sexual, encontrada também na tradição mítica. Há ecos nitidamente fálicos no afã excessivo do velho rei, que bate num viajante mais jovem e aparentemente indefeso com 0 mesmo "ferrão" com o qual atiça as mulas. Pois não é por acaso que os vasos clássicos projetam a grosseira afirmação sexual e a grotesca desmedida genital 
sobre as mulas com falos imensos que acompanham os sátiros itifálicos nos cortejos dionisíacos ou nos bacanais humanos (KERENYI, 1996).

Reunir os el ementos da desmedida e da rivalidade fálica não é uma interpolação indevida de idéias psicanalíticas, mas um esforço de reconstituição do imaginário clássico. Melhor dizendo: a análise freudiana da tragédia e do mito pode ter pecado ao ignorar os dados históricos e do imaginário clássico; ela pode ser escandal osamente indiferente à arte sutil com que Sófocles representou os antigos relatos míticos; e se permite, como mostrou Jean-Pierre Vernant, muitíssimos pressupostos interpretativos. Estes seriam, em resumo, pecados capitais na reconstituição histórica, com reflexos na poética e na psicanalítica. Mas, apesar destas falhas imperdoáveis, Freud teve o mérito de afirmar, numa época de puritanismo classicista, que há al go de sel vagem e primitivo na grandeza deste herói, traços de despudorados desejos priápicos que ignoram não apenas o senso estético puritano, mas atropelam todas as regras da convivência civilizada.

Se o vel ho Laio não observou o código de civilidade dos viajantes, atropelando o passante em pé como um centauro inebriado, seu filho multiplicou a desmedida, como ele mesmo salienta em seu relato. E retribuiu a grosseria do ancião cabeludo com a brutalidade maçante que os mitos destacam como característica dos centauros, ${ }^{4}$ famosos por abater e pisotear tudo o que atravessa seu caminho. Por mais que suas análises de Freud não correspondam às exigências metodológicas dos helenistas e por mais que suas formulações repitam a doutrina psicanalítica, é inegável - também em Sófocles - o horizonte do confronto fálico. Sob o verniz elegante do acabamento sofocliano, encontramos as marcas inequívocas da rivalidade primária, o ódio violento e repentino entre os homens de gerações sucessivas, o acesso desregrado e irrefletido que caracteriza a sexualidade dos priapos, pans e centauros, dos sátiros e silenos. Não é por acaso tampouco que o Coro se pergunte mais tarde se Édipo não seria filho de Pan, outro deus itifálico, verdadei ro daimon da natureza selvagem, que se destaca pela violência com que costuma raptar ou violentar as ninfas.

Quando Freud pergunta "por que Édipo Rei nos emociona tanto?", ${ }^{5}$ ele fixa nossa atenção sobre as vicissitudes psíquicas do parricídio e do incesto. Para Freud, o fascínio da peça corresponderia ao faro que todos nós teríamos pelo desejo oculto que compartilhamos com Édipo - o desejo de matar o pai e de

\footnotetext{
${ }^{4}$ Cf. Dover (1994): "Os centauros ( com a honrosa exceção do sábio Quiron) eram considerados, assim como os sátiros, criaturas de desejo sexual incontrolável, dados a pular em cima de qualquer pessoa, de qualquer sexo, cuja beleza os excitasse" (p.61). Além de rodeado por emblemas fálicos, Laio é também mencionado pela sua cabelei ra branca. Ora, o texto pseudoaristotélico Problemata (IV 31) discute a questão de saber " por que pássaros e homens cabeludos são lascivos?".

${ }^{5}$ Cf. as menções - demasiadamente rápidas - de Freud (1968).
} 
casar com a mãe. A um século de distância, perdeu-se o atrativo do tabu sexual quebrado pela psicanálise. Irrita-nos a rápida fórmula psicanalítica repetida em infinitos chavões que ofuscam a construção poética de Sófocles. Tivesse Freud reunido o dossiê completo dos traços fálicos que Sófocles coloca discretamente em lugares estratégicos, ele poderia ter citado Édipo Rei como ilustração de muitas questões psicanalíticas rel evantes, a saber: a perversão polimórfica, o desamparo (Hilflosi gkeit), a formação reativa. Isto com certeza não convenceria os helenistas e historiadores, cuja exigência de método tornaram-se muito rigorosas desde 0 estruturalismo. Mesmo assim, há um ponto importante que Freud soube captar graças à arte clássica (melhor dito: graças ao prestígio da aparência classicista que o público de sua época focava ao ol har para a Grécia). Freud soube captar o pavor oculto e inominável que todo signo acarreta (latente ou ativamente), pavor este que eclode de modo muito angustiante nas representações envolvendo a sexualidade, a procriação e a morte.

É legítimo, portanto, perguntar - dentro e fora do referencial freudiano o que significa a emoção que nos causa Édi po Ré? Não haveria algo nesta peça que nos toca no regime da angústia sem nome? 0 que é opressivo nesta peça não são tanto as representações do parricídio e do incesto, mas um clima, uma atmosfera intangível que Freud chama de "frẻ schwebendeAngst" - angústia livremente flutuante - , isto é, uma reserva de angústia que não encontra imagens concretas nas quais ela possa se fixar. A arte de Sófocles, sua economia dos traços que apenas indicam, não mostram, provoca aquela opressão que parece surgir de um perigo inominável, intangível e amórfico que paira no ar.

Não é um acaso o fato de o imaginário submerso (sunken imagery - como diz Musurillo [1957]) que Sófocles "enterrar" nos pântanos nebulosos de sua peça ser emprestado ao domínio da caça e da navegação, mundo dos perigos silenciosos e das armadilhas sorrateiras que favorecem este tipo de pavor. Mas tais imagens são diametralmente opostas às imagens racionais do rei empossado, que se orgulha de sua enquête transparente e pública. Trata-se de iluminar esta ambivalência dos traços que o herói descobre nas fases sucessivas de seu passado. Hölderlin foi o primeiro a sublinhar o outro lado, noturno e selvagem do herói. 0 poeta alemão menciona que a capacidade de salvar Tebas da Esfinge surgiu de um humor primitivo, de um faro selvagem: a palavra que 0 tradutor francês opta por "ardor", aparece, na tradução hölderliniana, como "o antigo sentido/ faro selvagem", der alte wilde Sinn ( paros prothymias) (HÖLDERLIN, 1988: H48, BL 48).

No entendimento do poeta alemão, o velho sacerdote invoca esta capacidade animal ou "daimônica" ao exortar o rei para que encontre outra vez uma solução para o flagelo atual. Como se houvesse duas fases na trajetória do herói - uma que o mostra como caçador selvagem, quase como jovem na fase da efebia, durante a qual os adolescentes atenienses dependiam inteiramente de seus instintos 
animais de sobrevivência, de lances rápidos e de ardis sorratei ros, e a outra sendo a fase do rei-sacerdote, solene e grave, encobrindo o humor irrequieto e alerta, obstinado e arrogante que faz de Édipo um duplo humano do titã Prometeu.

\section{O “VELHO MAL” dOS “PÉS INCHADOS”}

O herói da inteligência ágil e da determinação resoluta é, ao mesmo tempo, um "assombrado" que adivinha o segredo da natureza humana: a selvageria, a relação primordial com a aniquilação. É neste sentido que Hölderlin cunhou a famosa fórmula: "Parece que Édipo tem um olho a mais." O faro seguro de Hölderlin destaca os detal hes em aparência subordinados - as pequenas manifestações de insegurança e frêmito, de temor e desânimo, as incongruências das respostas e interjeções - que constituem, de modo subliminar, o eixo capital para a compreensão da tragédia. Em vez de se ater à brilhante superfície do herói inteligente e perspicaz, firme e decidido, o poeta fareja o avesso, que mina, sorrateiramente, esta existência. 0 tirano confiante de si e admirado pela coragem, perspicácia e decisão caminha sobre pés inseguros e este signo (da base comprometida) direciona e afeta sua compreensão, ora o guiando para os rastros mais relevantes, ora o impedindo de ver toda a sua significação.

$\mathrm{Na}$ cena inicial - a do pedido de socorro dos jovens e dos anciãos de Tebas - Édipo demonstra toda a presteza de um chefe perspicaz que previu as demandas do povo de Tebas e antecipou o plano de consultar o oráculo. A rapidez e a firmeza refletem a autoconfiança de um rei consciente do seu prestígio de 'desvendador' de enigmas. Ao mesmo tempo, entretanto, a cena coloca uma pergunta: Por que este rei tão perspicaz em adivinhar palavras enigmáticas, não foi, ele mesmo, consultar o oráculo de Delfos? Um dos traços mais salientes de Édipo é seu engajamento ativo, direto, quase corporal na ação. Unidas ao talento divinatório, estas características exigiriam que ele em pessoa perscrutasse as fórmulas ocultas - assim como Laio, que outrora não poupou o esforço de consultar em pessoa a pitonisa prestigiosa deApolo. Contudo, Édipo enviou Creonte, embora sua impaciência truculenta mal e mal suporte a demora do cunhado. Quais podem ser as razões da sua permanência passiva no palácio? De um lado, o envio de Creonte prova que ele não teme compartilhar os segredos apolíneos. No entanto, além deste zelo "democrático", há outras razões possíveis: a ida de Creonte poupava aos seus pés inseguros da fadiga da longa viagem, e Édipo, um tebano "tardio", como sublinha o texto, pode ter considerado que um autóctono teria melhores condições para dialogar com a pitonisa sobre as enigmáticas fórmulas do oráculo. Sabemos que a tradição clássica enfatizava, nas consultas ao deus de Delphos, o jogo de perguntas e respostas (MARSHALL, 2000). Neste sentido, Édipo mostra bom senso e realismo ao enviar Creonte, pois ele mesmo é, de fato, um cidadão alheio aos acontecimentos e segredos do passado. Embora goze de 
confiança e admiração irrestritas, sua aura heróica não apagou de todo o sentimento de certa inferioridade diante dos outros membros do palácio.

Sinais de algum incômodo quanto ao seu estatuto e sua legitimidade no trono tebano são as insistentes menções de Édipo à ascendência principesca de Laio. Bernard Knox (1971) vênesta insistência um signo do "sentimento profundo de inadequação relativa ao berço" que daria à fala de Édipo um tom "quase invejoso" (half envious) (p.56). Os estranhos non sequiturs do seu discurso, quando Édipo fala de Laio "como se fosse meu pai", são interpretados como lapsos psicológicos que teriam "a inconsistência típica de desejos inconscientes profundos que irrompem com violência na superfície da fala racional" (KNOX, 1971, p.56). Esta interpretação, que vincula o nível psicológico com implicações sociais e de classe, encontra reforço e confirmação no nível da insegurança física. Com efeito, os " pés inchados" que deram a Édipo seu nome são o estigma falante de um ferimento inexplicado, que a vergonha e o medo mergulharam em um silêncio tenaz. 0 "velho mal" e a "vergonha terrível" (archai on kakon, 1.044, deinon g'oneido sparganôns, a terrível vergonha das fraldas [ do berço que] eu contraí, 1.059) manifestam-se em sinais obscuros, inquietudes enigmáticas que permitem diversas leituras.

Hölderlin (1988) parte da hipótese de que Édipo tem, além do entendimento racional, um saber "adivinhado" (Ahnung) , 6 isto é, uma forma de intuição que não passa pela explicitação cognitiva de causas e efeitos. Adivinhar é saber obscuramente de "algo" sem poder conhecê-lo pelos meios do entendimento. Em Édipo Rei, este modo de saber não remete apenas ao assassinato e ao incesto do herói, mas, para além do crime cometido pelo herói, às atrocidades cometidas contra ele. A marca dos pés é o estigma do radical desamparo sob o qual ele nasceu e cresceu. Não é inútil mencionar que no gesto de Laio e Jocasta transparece a vontade de viver e procriar, vontade esta que caracteriza (e ameaça) a civilização deTebas desde o início dos tempos. Os Espartos transmitem aos seus descendentes o estigma da lança - lembrete de uma cadeia ininterrupta de mutilações e dilaceramentos mortíferos.

\section{A HISTÓRIA E O SENTIDO DA MUTILAÇÃO}

A gênese dos "pés inchados" é um detal he pouco comentado pelos exegetas de Édipo Rè. A análise estrutural do mito por Lévi Strauss evidenciou a falha do pé que assegura a coerência da lógica mítica. Mesmo assim, o "velho mal" que aflige os pés de Édipo costuma figurar tão somente como signo de reconheci-

\footnotetext{
${ }^{6}$ Cf. Hölderlin (1988, p.252), que assinala o potencial excêntrico do faro divino ao daimônico do herói: "No afã irado de adivinhar e intuir, o espírito de Édipo profere o nefas [ 0 juramento que condena ao exílio ou a morte 0 assassino de Laio]. Por isto, no diálogo seguinte com Tirésias, a maravilhosa curiosidade irada, porque o saber, quando rompeu sua fronteira, se atiça, [... ] para saber mais do que pode carregar e conter ou compreender."
} 
mento, um pouco como a cicatriz de Ulisses na Odisséia. Os intérpretes limitam sua atenção ao resultado visível da mutilação: inchaço e andar manco, sem integrar estes elementos na construção propriamente sofocliana da trama poética. Apenas Bernard Knox (1971) valorizou a gramática trágica que Sófocles constrói com as homofonias que ligam o "saber" e o "inchar", associando, de modo indissociável, o problema intelectual (as capacidades e os limites do saber) com o problema da limitação e da vulnerabilidade físicas.

0 comentário de Knox ilumina a pergunta do mensageiro quanto ao lugar onde se encontra o palácio de Édipo; faz alternar, sempre na posição final do verso, as sonoridades quase homofônicas do "saber onde" e do "pé inchado" (oim'hopou - Oidipou - oisth'hopou, BL 924-6):

Ar' an par' hymôn ô ksenoi mathoim'hopou / Estranhos, de quem posso saber onde

Ta tou tyrannou dômat'estin Oidipou/ Está o palácio do tirano Édipo

Malista d'auton ejpat'e katoisth'hopou. / M elhor, onde está ele mesmo, se souberem onde

Knox comenta o sentido desta afinidade fonética:

“[ ... ]Oidi- significa'inchar', mas sua sonoridade é muito próxima da oida, 'Eu sei' palavra essa que nunca está longe dos lábios de Édipo; é seu conhecimento que 0 torna o tyrannos decidido e confiante. Oida é recorrente em todo o texto da peça com a mesma persistência feroz de pous, e o potencial sugestivo inerente ao nome do tyrannos é ironicamente realçado num grupo de três assonâncias de fim de verso, cuja ênfase de trocadilho impiedoso é incomparável em toda a literatura grega." (1971, p.182183 , grifos nossos)

Aprofundemos a afinidade que a homofonia de oidi - e oida estabelece entre 0 inchar e o saber e que o comentário de Knox apenas frisa como um detalhe irônico. 0 nome-trocadilho liga de modo indissociável o saber e o defeito físico, a grandeza do herói e sua mutilação aviltante que o texto silencia até o momento da brusca nomeação pelo mensageiro - que a ela se refere como a uma obviedade que todo o mundo conhece. $A$ convergência do nome 0 idi pous com a potência intelectual (oida) e a impotência física (oidipous - pé inchado), sugere que a extraordinária habilidade intel ectual que legitima o poder de Édipo está diretamente inscrita na falha física. A marca indelével do desamparo e da ameaça que pairam sobre a condição humana parece desdobrar-se e superar-se no saber intelectual que doravante acompanha e encobre, porém não soluciona, o desamparo. A ágil inteligência de Édipo parece originar-se precisamente na ferida que causaram aos seus pés as ligas com as quais um pai medroso e hostil tentou inutilizar seus tornozelos. 
Qual é o sentido de amarrar os pés de um recém-nascido? Não há neste gesto nenhuma utilidade prática, a não ser que Laio já tenha antecipado a morte próxima, inibindo e mutilando os pés segundo a lógica arcaica do enfraquecimento da vítima. Esta lógica visa despojar a vítima da capacidade de desempenhar a força viril que poderia acionar uma vingança do além. Seja como for, tudo se passa como se Laio mutilasse o filho a fim de excluí-lo simbolicamente das atividades atléticas que habilitam o jovem guerreiro para a conquista do poder. Entregando a vítima mutilada a um pastor, ele a destina a perecer num espaço intermediário entre 0 mundo cultivado e o selvagem: as pastagens que beiram os agria, o mundo das feras e da caça. Neste mundo selvagem, não é incomum ver pequenas criaturas mortas e com pés atados. Mais um a vez evocamos os desenhos nos vasos gregos, os quais mostram cenas incontáveis com caçadores carregando pequenos animais pelos pés atados. ${ }^{7} \mathrm{~A}$ freqüência destas imagens indica que o hábito de atar e suspender um animal pelos dois pés diantei ros corresponde a uma prática convencional de transporte ( conhecida, aliás, até hoje) .

0 gesto de atar os pés é descrito duas vezes em Édipo Ré: Jocasta relata com riqueza de detal hes como Laio atou os tornozelos do recém-nascido e, num outro momento, o mensageiro-pastor descreve como desatou os membros perfurados pelas ligas apertadas. A insistência com que Sófocles ressalta este detal he facilita a associação que aproxima o filho humano do pequeno animal de caça. 0 ato brutal equivale a um rito que desumaniza a prole, prelúdio de uma matança que, primeiro, despoja o filho da casa real do seu estatuto principesco, para racionalizar e justificar a exposição da criatura "selvagem" nos precipícios das al tas montanhas, no espaço dos animais selvagens. Apesar da economia extrema, o texto de Sófocles indica com clareza as etapas deste ritual atroz, que substitui a ordem humana pela do mundo animal e selvagem.

\section{FILHO DE PÃ OU IRMÃO DE PROMETEU? ÍMPETOS DE TITÃS E DE DAIMONES COMO ARMA CONTRA O DESAMPARO}

São bem conhecidos os traços desconcertantes que lançam sombras sobre a imagem de Édipo. Sua "ira" (orgé) é como uma força cósmica, um daimon que age através deste herói. ${ }^{8}$ Sua obstinação e impaciência - um humor irascível que dá

\footnotetext{
${ }^{7}$ Alain Schnapp (1997, p.321-325) mostra as imagens de retornos da caça, entre muitas outras, nas figuras 153 a 158: o caçador carrega no bastão apoiado sobre o ombro lebres ou raposas atados e suspensos pelos pés. Assinal emos que estas imagens da pequena caça (lebre, raposa, etc.) reaparecem como um estereótipo redundante até a figura 401 . Na figura 317, vêse um caçador com uma lebre suspensa pelo bastão e ele se aproxima de um priapo; na 318, uma lebre é suspensa numa coluna diante de um altar sobre o qual paira Hermes; na 319, há a representação, de um lado, um casal homossexual abraçado e nu, do outro, um homem cuidadosamente vestido, oferecendo uma lebre a uma senhora que tece. Schnapp ressalta que
} 
uma coloração específica à inteligência perspicaz deste herói - lembram a implacabilidade assombrosa de Prometeu, a authadia que faz o grande titã resistir às ordens de Zeus. Sua sutileza e aguda perspicácia não se manifestam apenas num orgulho confiante e seguro no êxito das iniciativas tomadas. Nos gestos e nas palavras deste herói invejável mostra-se, desde o início, alguma truculência irrequieta, que destoa da segurança tranqüila assumida ao se comprometer publicamente em salvar a cidade.

A truculência com a qual Édipo persegue sua missão explode em excessos de cólera (MÉAUTIS, 1960, p.101), iras loucas e sem o menor traço de inibição ou arrependimento; estes atos derramam-senão só contra Creonte eTirésias. 0 modo como o rei Édipo conta sua "triste vitória" (p.109) sobre o ancião e seu pequeno séquito na encruzilhada revela um "ato absurdo que se explica tão somente por este furor passional, furor de cólera sanguinária que sobe do mais profundo de Édipo, da própria alma da raça maldita [... ]" (p.109). Apesar das aparências de racionalidade e clarividência, Sófocles faz sentir que Édipo carrega a tara de sua estirpe, isto é, uma cólera destruidora e autodestruidora legada pelos antepassados monstruosos ( os spartoi). 0 relato da matança na encruzilhada revela o pano de fundo do qual brota a cólera de Édipo: há o mesmo orgulho colérico também na arrogância desdenhosa do vel ho Laio golpeando, do al to do seu carro, o viajante desconhecido que reluta em Ihe ceder a passagem.

Sófocles contrabalança estes traços pulsionais e, em certos momentos propriamente selvagens, com as qualidades da razão, da investigação metódica. Édipo é ao mesmo tempo admirável elamentável em sua laboriosa averiguação dos encadeamentos de causas e efeitos, seu esforço de deduzir dos parcos indícios que fazem a investigação enveredar pelo labirinto de erros e esquecimentos crassos - revisitando-os um a um, com uma perseverança estranha que submete ao escrutínio calculado não apenas os fatos, mas também os menores detalhes que surgem na sua percepção.

Knox valoriza as qualidades que o próprio Sófocles sublinha (pelo menos num primeiro momento) como as características do herói: a inteligência perse-

\footnotetext{
estas três figuras ilustram a modificação do imaginário grego clássico: na primeira e na segunda ( fundo negro, do século VI), o tema da caça está vinculado com o prazer específico do espaço selvagem e dos hábitos violentos que lhe correspondem (caça sangrenta e uniões sexuais selvagens simbolizadas por Priapo, Pã, etc.); na última (fundo vermelho, século V), tudo se passa visivelmente no espaço fechado do lar, com seus rituais sofisticados (vestimenta requintada e as atividades correspondentes: fiar, tecer, bordar).

${ }^{8}$ Trajano Vieira (2001) assi nala as ocorrências explícitas desta sobredeterminação nos seguintes versos: BL 816, 831 ekhthrodaimon (homem mais odiado pelos deuses); BL $828=842$ : ómou daimon, dai mon cruel; BL 1.189-95 = 1.201: daimon de Édipo é exemplar (paradigma) da humanidade; BL 1.297-1.303 = 1.308 que daimon lançou-se sobre teu destino miserável (moira dusdaimoni).
} 
verante e metódica, a ação decidida e corajosa, dando sua forma específica à investigação levada a cabo pelo herói. Com efeito, Édipo confia no controle racional e na elucidação factual dos enigmas que o destino coloca no caminho da existência humana. ${ }^{9}$ Édipo é vítima de si mesmo, cai nas armadilhas que ele mesmo colocou, construindo com vigor - e contra a resistência de toda a corte e de todas as testemunhas - a rede de provas da sua investigação.

Fiel à conquista prometeica, Édipo aparece como o paradigma do indivíduo autônomo, insurge-se contra os obscuros signos do destino, mobilizando toda a sua coragem e seu conhecimento com o intuito de ver claro (e fica cego no final). É neste plano que Édipo é um dos modelos da autoconsciência moderna. Do ponto de vista histórico, ele representa a autonomia do tyrannos grego, que conquista seu estatuto por meio do próprio valor, sendo o indivíduo que se afirma no jogo agônico do mútuo reconhecimento. Neste sentido, ele éo sujeito racional que funda e se submete livremente à medida do conhecimento calculável e às regras do saber comunicável e público que viabilizam a sociabilidade democrática. No entanto, este primeiro plano se inverte para revelar o herói da vergonha, o qual se descobre como objeto de uma repulsa universal (MÉAUTIS, 1960, p.106).

Mais humano que o titã de Ésquilo, Édipo tem o mérito deste quando sabe fazer esquecer a morte: ele oferece generoso consolo, enternecendo-se como Prometeu, com o sofrimento dos homens e empenhando-se com obstinação em salvá-los de um triste destino. ${ }^{10} \mathrm{~A}$ ação heróica de Prometeu é sustentável, para os mortais, graças apenas ao esquecimento da morte. 0 titã salva a humanidade, concedendo aos homens "cegas esperanças" ${ }^{11}$ Édipo transforma este dom divino numa das qualidades típicas do caráter ateniense. Atenas se orgul hava da firmeza dos seus chefes nas situações mais adversas, e das vitórias obtidas graças à ação resoluta em momentos críticos, itens que inspiravam a outras cidades cautela e prudência. E os inimigos e rivais de Atenas exaltavam sua magnífica capacidade de prevenir 0 ataque, antecipando-se sobre os planos dos adversários (KNOX, 1971)..$^{12}$

A capacidade de antecipar os perigos - eis a esperança prometeica de Édipo. $\mathrm{N}$ a sua preten são de refletir, agir e solucionar as carências da existência humana,

\footnotetext{
${ }^{9}$ Cf. Trajano Vieira (2001, p.21-22). Ele tem reservas com relação à leitura racional de Knox, concedendo papel mais importante às forças demoníacas e ao destino do que o crítico norteamericano.

${ }^{10}$ Cf. a análise da rapidez e da impaciência em Knox, 1971, 41 ss.

11 "Livrei os mortais da visão da morte", explica Prometeu ao Poder (Kratos), que o prende à rocha do seu suplício. Este Ihe pergunta: "Qual o remédio que encontraste para curá-los disto?" E Prometeu responde: "Ergui neles cegas esperanças." (Prom. Acorr. 248-250).

${ }^{12}$ Cf. Knox (1966, p. 63 e, mais especificamente, 67, 98 ss).
} 
ele rivaliza com o herói de Ésquilo e de Hesíodo. São os ardis dos divinos tricksters que inspiram ao homem miserável sua desmedida confiança nos recursos do conhecimento e da invenção (techne) - embora estes truques repousem sobre um fundamento precário. Eis a razão pela qual Ésquilo e Sófocles comparam as esperanças humanas às ilusões de pássaros cegos e sonhadores ( Antígona, vv. 346, $618,357,616)$. Mesmo assim, ambos os heróis são obstinados e não temem rivalizar com os deuses, com Apolo, Zeus e Atena. Knox (1971) comenta esta pretensão que forma a base para o desenlace da reviravolta trágica:

“Édipo chama-se a si mesmo de 'grande' (megan, 442, cf. 776), mas o deus, diz 0 coro, é'grande' nas suas leis (megas theos, 872). Édipo possui seu 'império' (archê, 259, 383), mas o império de Zeus é imortal (athanaton archan, 905). Édipo promete 'força' (alkên, 218, cf. 42), mas é para Atena que o coro pede 'força' (alkan, 189). Édipo fala com os tebanos como um pai com seus filhos (tekna, $1 ;$ cf. 6), mas o coro finalmente apela para o 'pai Zeus' (Zeu pater, 202). Édipo 'destruiu' a Esfinge (phthisas, 1198), mas é para Zeus que o coro apela a fim de 'destruir' a peste (phthison, 202). Todos estes ecos são como um deboche das pretensões de Édipo e, além disto, a linguagem da peça ressoa com trocadilhos sardônicos sobre seu nome que parecem insinuar-se nas falas dos caracteres como ecos de longínquas e duras risadas. Oidi pous - "Péinchado" éum nomeque enfatiza a falha física que marca o corpo do tyrannos esplêndido, uma falha que ele gostaria de esquecer, mas que nos lembra a criança rejeitada que ele foi uma vez e que ele está prestes a tornar-se novamente." (KNOX, 1971, 182-3, grifos nossos)

Na tragédia de Ésquilo, são os irmãos do Titã que ressaltam, medrosos, os limites impostos pela lei de Zeus. E Hermes, o mensageiro do deus olímpico, debocha da infel iz combinação de orgulho com impotência e sofrimentos. Com efeito, Ésquilo faz de Prometeu acorrentado a imagem engrandecida e divinizada de uma dimensão essencial da condição humana - a do "ser incuravelmente desamparado e ferido" (KERÉNYI, 1959, p.35 ss). Prometeu é o “irmão" da humanidade na medida que suporta o sofrimento (suspenso a uma rocha nos confins extremos da terra, vv. 15-24 [KERÉNYI, 1959, p.90]) sem abdicar de suas obstinadas pretensões. Esta mistura de força e desamparo torna particularmente tocante - e "humana" - sua imperturbável confiança na reviravolta longínqua.

Sófocles nos fornece a versão plenamente humana da figura titânica e divina da sabedoria: diferentes maneiras e formas de saber que constituem, no entender de Hölderlin, o núcleo central do herói sofocliano. 0 poeta alemão não centra sua interpretação nos signos de inteligência e determinação do " rico e esplêndido autocrata" (KNOX, 1971, p. 98). Ele enfoca, além da sua inteligência racional, as obscuras desconfianças, as formas vagas de saber que guiam e desviam a investigação racional. Édipo adivinha, desde o início, não-ditos assombrosos que os 
habitantes do palácio e os cidadãos deTebas ocultam na sua memória. Hölderlin assinala que o pensamento de Édipo se tornou "inseguro" porque está "sobrecarregado por tristes segredos" (FHA 253) e sofre de intuições ou "adivinhações iradas" (zornigeAhnung, FHA 252 ) para além da compreensão. Édipo é ao mesmo tempo o herói ativo, cru e irado ${ }^{13}$ e a vítima de um obscuro assombro. 0 que atormenta Édipo é um saber que o entendimento finito "não pode carregar, nem compreender" (FHA 253), um saber que inspira um pavor surdo e inarticulado, subtraído à representação. Este tipo de pavor tem todas as características do medo imediato e inominável, do Grauen que não se manifesta em imagens disponíveis para uma elaboração cognitiva, mas que se manifesta por reflexos quase corporais de retração e de agressividade, de rechaço e defesa imediatos.

Recebido em 9/ 3/ 2005. Aprovado em 13/ 4/ 2005.

${ }^{13}$ As "Observações" de Hölderlin pontuam o texto com os seguintes comentários:

"No afã irado de adivinhar e intuir, o espírito de Édipo profere o nefas [ atribuindo um sentido particular à pal avra sagrada]. Por isto, no diálogo seguinte com Tirésias, a maravilhosa curiosidade irada, porque o saber, quando rompeu sua fronteira, se atiça, [... ] para saber mais do que pode carregar e conter-compreender."

Por isto, na cena com Creonte, logo após, a suspeita, porque o pensamento indomado e carregado pelo peso de tristes segredos torna-se inseguro, e [porque] o espírito fiel e meticuloso sofre na desmedida irada, a qual, al egre de destruir, apenas segue o tempo torrencial.

... quando Édipo está novamente tentado a viver, inicia o combate desesperado para voltar a si mesmo, o esforço brutal e quase despudorado de dominar-se a si mesmo, a procura loucamente selvagem por uma consciência....

Justamente este esforço que tudo procura, tudo interpreta, faz com que o espírito sucumba, no final, à linguagem rude e simples dos seus servos.

U ma vez que tais homens estão em relações violentas, sua linguagem fala, quase ao modo das Fúrias, numa conexão mais violenta." (HOLDERLIN, 1988). 


\section{REFERÊNCIAS}

DOVER, K.J. (1994) A homossexualidade na Grécia antiga, São Paulo: Nova Alexandria.

FREUD, S. (1968) GesammetteW erke. Frankfurt am Main: Fischer, v.II/ v.III (p.267-271); v.XI (p.342-344), v.XIV (p.412 s).

HOLDERLIN, F. (1988) "Anmerkungen zum Oedipus" (Observações sobre Édipo), in SämtlicheW erke, Frankfurter Ausgabe, v.16, Stromfeld/ Roter Stern.

KERENYI, K. (1959) Prometheus, Hamburg: Rowohlt. . (1996/ 1999) Dionysos, Princeton University Press.

KNOX, B. (1966) The Heroic Temper, University of California Press. . (1971) Oedipus atThebes. NovaYork: The Norton Library.

MASON, Paul ( 1985) Sophocle, Oedipe Roi, Paris: Lês Belles Lettres.

MARSHALL, F. (2000) Édipo Tirano - a tragédia do saber. Porto Alegre: Editora daUFRGS.

MÉAUTIS, M. (1960) L'authenticité et la date du Prométhée Enchainé d'Éschyle, Génève-Neuchâtel:Payot.

MUSURILLO, H. (1957) Sunken imagery in Sophokles' Oedipus (AJPH, LXXVIII). SCHNAPP, A (1997) Lechasseur et la cité. Paris: Albin Michel.

VERNANT, J. P. (1972/ 1978) Mythe et tragédie em Grèce ancienne, 2 v., Paris: Maspéro.

VIEIRA, T. (2001) Édipo Rei de Sófocles. São Paulo: Perspectiva.

Kathrin Holzermayr Rosenfield

kathrin@terra.com.br 